\title{
Beyond employer engagement and skills supply: building conditions for partnership working and
}

skills co-production in the English context

Ann Hodgson, Ken Spours, David Smith and Julia Jeanes

Centre for Post-14 Education and Work

UCL Institute of Education, London, UK

Article for submission to Journal of Education and Work

Corresponding author: Professor Ken Spours

UCL Institute of Education, 20 Bedford Way, London WC1H OAL

k.spours@ucl.ac.uk 


\begin{abstract}
Education providers and employers working together to prepare young people and adults for employment is internationally accepted as a key factor in effective technical and vocational education. In the English context, however, we argue that two related orthodoxies have prevailed - 'employer engagement' and 'skills supply' - in which education providers have striven to gain employer involvement in their programmes and meet their skills needs. The effectiveness of these twin orthodoxies has been limited by the 'New Low Skills Equilibrium' (NLSE) involving a symbiosis of weaknesses on both the education and employer sides. The article draws on findings of a two-year research and development programme in East London which explored the process of education-employer partnership working to support inclusive growth in key economic sectors. The research suggested that this aim was best supported by processes of 'co-production' that actively involved both partners in attempting to address features of the NLSE. The research also pointed to constraining factors. The article concludes by identifying the conditions required for the realisation of co-production approaches that include the development of new collaborative structures - High Progression and Skills Networks (HPSNs) - involving a wide range of social partners at the local and regional levels.
\end{abstract}

Key words: education-employer partnerships, further education colleges, skills, employer engagement, England 


\section{The employer engagement orthodoxy}

The idea that education providers and employers should work together in order to prepare young people and adults for employment is far from new. Countries diverge in terms of the governance arrangements in place for this type of activity (Clarke and Winch 2007), but it is normally seen as a vital aspect of technical and vocational education and skills development (EC 2010, OECD 2014).

Although work experience for some programmes was already being funded by government in England in the 1960s (Mann, Rehill and Kashefpakdel 2018), arguably the real beginnings of education and business working together to enhance English upper secondary education can be traced back to the Technical and Vocational Education Initiative (TVEI) in the late 1980s ${ }^{1}$ and the subsequent rise of Education Business Partnerships ${ }^{2}$ that burgeoned in the 1990s. From that time onwards, a plethora of policy documents from a range of government departments and agencies have exhorted education providers of all types to work with employers on a multitude of different curriculum and qualification initiatives (see Macleod and Hughes 2005, DBIS/DfE 2016), as well as more obviously work-based programmes, such as apprenticeships and traineeships (HMG 2013). While employers have also been encouraged to work with education providers, on the whole it is the latter who have been expected to take the lead in this activity, hence the commonly-used term 'employer engagement'.

\footnotetext{
${ }^{1}$ The Technical and Vocational Education Initiative (TVEI) was a government funded curriculum development programme that began in 1983 and ended in 1997. Its stated aims were to: widen and enrich the curriculum, prepare students for the world of work, help students lead a fuller life, enable students to contribute to the life of the community, enable students to adapt to a changing occupational environment, to help students to 'learn how to learn' (see Moon and Richardson 1984; Bridgwood 1987).

${ }^{2}$ Until 2011, Education Business Partnerships (EBPs) were government-funded agencies that supported partnership working between employers and education providers. Many still exist in different parts of the country sponsored by a range of organisations and supported by the Association of Education Business Professions - https://theaebp.wordpress.com
} 
This idea became an orthodoxy - a dominant way of thinking about education/employer relations - and is closely allied to another orthodoxy, 'skills supply', which maintains that the role of education is to supply the skills that employers say they need. Both terms suggest a one-way relationship rather than a genuine two-way partnership in which both education providers and employers seek to work together in new ways from which both benefit and through which both are transformed.

\section{The New Low Skills Equilibrium}

The 'one-way streets' of the twin orthodoxies face deep-seated historical problems rooted in low employer demand for skill in the UK. In the late-1980s Finegold and Soskice, originators of the term, described the Low Skills Equilibrium (LSE) as a situation:

in which the majority of enterprises are staffed by poorly trained managers and workers produce low-quality goods and services. The term 'equilibrium' is used to connote a self-reinforcing network of societal and state institutions, which interact to stifle the demand for improvements in skill levels (Finegold and Soskice 1988, 22).

According to Finegold and Soskice, the main features of the LSE comprised a dynamic between problems on the employer and the education sides. On the employer side, these included the decline of manufacturing and a shift towards a low-quality service sector economy; recruitment of unskilled school leavers and little incentive for young people to participate in higher education (HE); poorly trained management; an increasingly financialised economy with weak investment in industry; and a free market approach to labour markets. The education side, on the other hand, suffered from low levels of post-16 education participation; the domination of the academic curriculum and an under-developed 
technical education tradition; and poor national co-ordination of training; resulting in too few technically trained young people compared with systems such as Germany and Austria. Finegold and Soskice argued that the LSE could only be overcome by a series of structural education and labour market reforms in the UK and the development of a social partnership model similar to Germanic and Nordic systems.

This partnership path, however, has not been followed in the UK (particularly England) over the past 30 years due to the dominance of what have been termed Anglo-Saxon economic and education reform models (Hodgson and Spours 2014). Some three decades later, therefore, England in particular finds itself in what we refer to here as a New Low Skills Equilibrium (NLSE). On the employer/employment side several of the LSE features have intensified the move away from manufacturing, the financialisation of the economy and the lack of investment in training and industry, which have contributed to a productivity crisis (Tenreyo 2018). But there are also new industrial and business features, including the growth of the tech and finance sectors alongside a casualised 'gig economy' (Todolí-Signes 2017, Muntaner 2018); the increased use of outsourcing and a reduction in the size of the public sector (Wettenhall 2001, Bach 2016). The combination of old and new business and industrial patterns has seen a demand for high-end skills focused on the flow of HE graduates with recourse to foreign labour to meet both high- and low-skill demands (Green and Hensenke 2016, Wadsworth 2015). The overall result has been the development of what has been termed an 'hour-glass' economy with a dynamic situation at the top and bottom, but with the demand for intermediate level skills, associated with technical jobs, manufacturing and careers for young people, substantially reduced (UKCES 2014). 
On the education side, there have been some important developments in the intervening decades. Levels of post-16 education participation have risen dramatically, as has the size of the HE sector, but with the continued domination of the academic curriculum and examination system (Hodgson and Spours 2014). In addition, the education system has fragmented as a result of marketisation, making it more difficult to have a co-ordinated approach to vocational education (Keep 2015). While those young people progressing to working life are generally better educated than was the case 30 years ago, education outputs have been largely the result of the growth in academic qualifications and the expansion of the higher education sector rather than technical and vocational skills (Universities UK 2015). The dynamics of the NLSE, while somewhat different from the original LSE, continue to negatively impact on education/employer relations. Compared with the past, a much larger but relatively economically detached education system intersects with business and industry that does not primarily focus on young people from the UK, a process associated with a decline in youth jobs in many sectors (EY Foundation 2016).

\section{The employer engagement orthodoxy - an evolving literature}

A brief review of historical and policy literatures on education/employer relations suggests that they largely reflect the NLSE. However, more recent publications appear to be showing a greater appreciation of mutually beneficial relations associated with 'two-way street' partnership working.

\section{A focus on schools}

In the context of historical education expansion, mainly in the academic/general route rather than in work-based learning, most literature on 'employer engagement' relates to schools and discusses the benefits that accrue to young people from employer interventions of various 
kinds (e.g. mentoring, careers talks, work experience). The Education and Employers Taskforce has assiduously pursued this theme through research, literature reviews, publications, toolkits and programmes and concluded that: “effective' engagement is where the cumulative total of partnerships provides an individual school or college with engagement that is broad, impactful, mutually beneficial and relevant to institutional circumstances." (Education and Employers Taskforce 2009, 4). It is useful to note in this definition that the emphasis is clearly on what schools and colleges (although the latter are largely absent from the report) gain from the partnership. The benefits to education and to the learner have been echoed in more recent research (e.g. Mann, Rehill, and Kashefpakdel 2018; Mann and Percy 2013; Huddleston, Mann, and Dawkins 2014). Moreover, employer engagement activities are categorized into 'supplementary', 'complementary' or 'additional'. In other words, however beneficial they may be, they are not perceived as essential to the learning process.

Recent international studies on education-business partnerships also tend to focus on schools (e.g. Flynn, Pilley, and Watters 2016; Polesel et. al. 2017; Rusten and Hermmelen 2017; Hernandez-Gantez, Keighobadi and Fletcher 2018), although there is a greater emphasis on the need for benefits for both parties. Flynn, Pilley, and Watters (2016), a study based in Australia, and Rusten and Hermelen (2017), based in Sweden and Norway, additionally note the importance of being sensitive to local and regional contexts with their different spaces for action. This is an important issue to which we return later in the article.

There have also been a number of studies that explore or assess employer engagement in HE institutions (e.g. Dhillon, Edmonds, and Felse 2011; Melhuish 2017). The purpose of these activities in some HE programmes is often more akin to those in further education (FE). However, the significant differences in the way FE and HE institutions in England are 
governed and funded means that the contribution of these studies to knowledge and practice about education-employer partnerships in FE in England is limited.

\section{Employer engagement in further education: the skills supply orthodoxy}

For FE colleges, which specialise in technical and vocational education, working in partnership with employers is an essential aspect of the learning opportunities and programmes they provide. However, the literature related specifically to FE colleges and employer engagement has focused mainly on what colleges should be doing for employers. It should be noted that the role of employers in apprenticeship and work-based learning has been extensively analysed and discussed elsewhere (e.g. Fuller and Unwin 2003, 2010; Dolphin and Lanning 2011) and is not in scope here.

During the late 1990s and 2000s, the plethora of policy documents related to further education (e.g. DfEE 1998, Foster 2005, DfES 2006) signalled the importance that the New Labour Government of the time placed on this sector to deliver its skills policies. All of these documents exhorted FE providers to engage with employers to improve both the quality of technical and vocational education and to enhance skills development. In this sense, policy was focused primarily on 'skills supply' by education providers because they were seen as inadequately preparing young people for work or addressing 'skills gaps' and 'skills shortages' in the UK labour market (see Keep 2012 for a critique of this view of the 'orthodoxy').

\section{Beyond the 'one-way street'}


Following the publication of the Wolf Review of Vocational Education (Wolf 2011), however, a number of influential studies, while sometimes still using the term 'employer engagement', began to go beyond the supply-side, education-dominated discussions, thus signaling an attempt to examine the issue from an employer as well as an education provider perspective and seeking to build a more balanced relationship that provides benefits for both sides.

This relationship with employers was emphasised, for example, in the Commission for Adult Vocational Learning report, It's about work... (CAVTL 2013) that moved the discussion on 'employer engagement' in the FE and skills sector forward through its introduction of the phrase 'two-way street'. This term was used to describe deep collaboration between employers, colleges and work-based learning providers which not only involves all parties in planning and delivering vocational programmes, but also suggests activity that has benefits for both employers and education providers.

This change in terminology and approach was picked up in A New Conversation: Employer and College Engagement (UKCES/157 Group/Gazelle Colleges 2014). It suggested that FE colleges needed a better understanding of business and entrepreneurship, led from the top but strongly threaded through the whole organisation, allowing college staff to talk confidently with employers about economic trends locally and regionally. This, it was asserted, would enable them to build long-term partnerships that would give them a clear role in their economic community and provide them with the stability and reputation to weather shortterm economic and policy turbulence.

FE-specific literature also stressed the importance of the local and regional scale for partnerships working (e.g. Sharp 2011, LGG/BCC/157 Group 2011) as a counter both to the 
type of top-down national policy that the FE sector had experienced in different forms since incorporation (Hodgson and Spours 2015) and in support of government policies that stressed the need for greater localism (e.g. HoC 2011).

Two London-specific publications during this period illustrate the position on collegeemployer partnership working in the Capital. The first reported on research undertaken by the National Institute of Adult and Continuing Education (NIACE) ${ }^{3}$, London FE Colleges' Employer Engagement (Berry et al. 2014), which found that only seven per cent of employers in London used FE colleges as an external training source and only 12 per cent offered apprenticeships, the lowest regional figure in England. The reasons for not using colleges more extensively included: lack of relevant courses, lack of information about courses, and the perception that provision was of poor quality, too expensive and inflexible.

A report from the Office for Standards in Education, Engaging small and medium enterprises (SMEs) in work experience and apprenticeship in London (Ofsted 2015), highlighted some of the challenges of employer engagement, including the lack of time and personnel that SMEs have to engage in work experience or apprenticeship and their doubts about the benefits of the former to their company. SMEs also complained about the confusion caused by multiple demands from education providers and the amount of bureaucracy involved in both apprenticeships and work experience.

\section{The evolving messages from the literatures}

The bulk of the literatures on employer engagement over recent decades could thus be seen to reflect problems at the heart of the NLSE - an expanded education system that lacked

\footnotetext{
${ }^{3}$ This organisation is now called the Learning and Work Institute - see http://www.learningandwork.org.uk
} 
relationships with working life and the need for FE to supply skills for employers, despite the fact that employers were not always capable of generating consistent high demand for skill (Keep 2012). However, as we have seen above, more recently national and London studies have talked about building sustainable relationships where trust and mutual respect lead to long-term joint working that has benefits for all parties - employers, education providers, their learners and the broader community (in this regard see also grey literature such as, UCL IOE/AELP/ETF (2016), Hodgson and Smith (2016)). They note the benefits of using and forming collaborative networks where the key social partners within a sector or a locality, sub-region or region can enter into an honest dialogue about how together they can support the economic and social development of that area. And, equally importantly, the recent literature stresses new ways of working that are more flexible, relevant and future-focused.

\section{The ELVET Programme: exploring education- employer partnership working (2016-} 18)

'Employer engagement', despite its ubiquitous use, is not an appropriate term for the type of activity described above. It suggests a one-way relationship in the interests of the provider, rather than a genuine two-way partnership that yields benefits for providers, learners, employers and the wider community. In the East London Vocational Education and Training: Innovation Through Partnership (ELVET) Programme we argued for the term 'education-employer partnership' as more appropriate for the type of activity that was and is required in East London and it to this research that we now turn.

Grant funded by the JPMorgan Chase Foundation, ELVET was launched at a time when the local economy in East London was seeing a huge change with the influx of new industries and services. At the same time, major national reforms within the FE and skills system were 
taking place in areas such as apprenticeships, qualifications for adults and young people and institutional organisation.

Given this context, the ELVET Programme's aims were to:

- Facilitate access to training and employment in the digital, creative and health and social care sectors in East London, particularly for people from low-income backgrounds.

- Develop strategic and sustainable relationships between East London colleges and employers, resulting in more relevant and up-to-date technical and vocational provision aligned with the regional government's skills priorities.

- Improve learning, employment and apprenticeship outcomes and progression pathways into and within work, thereby contributing to the thinking on social ecosystems and the creation of 'High Progression and Skills Networks' in East London and beyond.

ELVET was directed by a London university research centre with support from the Association of Colleges London Region. The researchers oversaw and acted as critical friends to four innovation projects in three sectors - digital tech, the creative industries and health and social care - that were led by three London FE colleges in partnership with a range of sector-specific employers and other education and training providers.

These sectors are important for the overall economy in London and for East London in particular, but employment is not always accessible for the populations living in East London because of skills deficiencies and national and international competition, particularly for higher level jobs in the digital tech and creative industries (Mayor of London 2016, GLA 2018). Hence the focus of three of the ELVET innovation projects, which were led by a college middle manager with a curriculum specialism. 
College A: Site 1 focused on creating partnerships with employers in the Digital Tech sector to help students to progress to apprenticeship, higher education and employment. The project in College A: Site 2 was designed to support students to understand and effectively prepare for employment and HE opportunities in the Creative Industries ${ }^{4}$. College B explored how partnership working with employers could help to upskill the workforce in the health and social care sector. The fourth innovation project, led by College $\mathrm{C}$, had a role to research and then develop successful models of education-employer partnership working across the three sectors in order to support the work of Colleges A and B as well as other education providers in East London. Because of their location, all the college sites serve young people and adults from lower socio-economic groups and from highly diverse ethnic backgrounds.

\section{The contexts for the research}

The findings from the ELVET programme need to be understood within the national, London-wide and sub-regional contexts that provided the wider and immediate terrains in which the NLSE was experienced and that offered both opportunities and constraints for partnership activity and skills co-production.

\section{National education and training policy}

The ELVET Programme took place at a time of great policy changes in England that often appeared to pull in different directions. Austerity was present from 2010, with severe funding constraints being imposed on post-16 education, thus reducing education providers' capacities to respond to skills development needs. The Brexit decision in June 2016, on the

\footnotetext{
4 These two college sites were originally two separate colleges, but merged during the period of the ELVET Programme so are indicated as College A: Site 1 and College A: Site 2.
} 
other hand, focused policy attention on the need for home-grown skills development (see DBIS/DfE 2016, HMG 2017) and closer working relationships between providers of vocational education and employers.

In addition, a set of specific post-16 education and training reforms introduced considerable turbulence into the FE and skills system and certainly provided distractions for colleges attempting to focus their attention on education-employer provider partnership working. In terms of qualifications and assessment, substantial changes to academic and vocational qualifications have been introduced since 2010, primarily centred around a greater proportion of external examination and less continuous assessment, with implications for education inclusion. Further change is underway as a result of the Government's Post-16 Skills Plan (DBIS/DfE 2016). A total of 15 technical routes and associated Level 3 T-Level qualifications, based on new apprenticeship standards, are being developed for first delivery in 2020, with an emphasis on making vocational education more 'rigorous' and employmentfocused and with a greater role for employers in its design. Apprenticeships have also been reformed; moving from apprenticeship frameworks to apprenticeship standards, with the Apprenticeship Levy to help secure the Government's target of three million apprenticeship starts by 2020 (HMG 2015a). During the period 2015-17 Area-Based Reviews (ABRs) (HMG 2015b) took place involving England's FE and sixth form colleges and designed to reduce costs in post-16 education through the creation of larger FE institutions or federations that could also respond more effectively to employer needs on a sub-regional or regional basis.

\section{Devolution policies}


Alongside vocational reforms, devolution policy was also being developed and had an important influence on skills policy in those regions which it affected. The Cities and Local Government Devolution Act (HMG 2016) was designed to introduce directly elected mayors to combined local authorities in England and Wales and to devolve housing, transport, planning and policing powers to them - a process known as 'devo deals'. The London 'devo deal' also included the devolution of the Adult Education Budget and discretionary support for 19+ learners. In addition, during the lifetime of the ELVET Programme, the London boroughs, together with the Greater London Authority (GLA), put forward a number of plans for sub-regional skills development within the London Skills Devolution Plan (London Councils/London Enterprise Panel/Mayor of London 2015) and the Mayor's Skills for Londoners Strategy (GLA 2018).

\section{London and its New East: a prime site for the NLSE}

The geographical location of the ELVET Programme was also a powerful shaping factor in its design and implementation. London is the UK's economic powerhouse, specializing in high value business services (e.g. finance and insurance), cultural industries, HE and digital tech (London First 2018). Employment opportunities and higher pay in Central London, together with plentiful transport links, mean that employers can attract people from the whole of the UK and from abroad.

While London has an expanding labour market, it is polarized. High-level professional jobs are accompanied by a proliferation of low-skill and low-level jobs and the hollowing out of intermediate occupations, with a relative inability to produce 'youth jobs' or work-based learning opportunities at Levels 3 and 4 (Holmes and Mayhew 2012). At the same time there are substantial skills shortages in the digital and creative, construction and health and social 
care sectors (Thompson, Colebrook, and Hatfield 2016). London also suffers from social division - high levels of wealth concentrated among a small minority, accompanied by considerable in-work poverty, private renting and people living in temporary accommodation (NPI 2017), giving rise to geographically concentrated areas of poverty, focused in London's North and East.

London is moving eastwards as the economic and technological developments in the City and 'Silicon Roundabout' overheat and the eastern boroughs are seen as places where London can expand in economic and population terms (London Growth Boroughs 2016).

Although each part of London's East, the setting for the ELVET Programme, has its own dynamics, they are also part of Greater London and the Mayor's 'spatial masterplan' that aims for large areas to be redeveloped as a whole within the concept of a socially and economically rebalanced London (Mayor of London 2016). In addition, as with the national policy agenda, there has been an increasing focus for the Mayor and the GLA on skills development for the London population (GLA 2018). In contrast to the national drive in this area, however, there is an emphasis on inclusion and accessibility as well as international competitiveness and productivity. So, a major rationale behind the ELVET Programme was both to investigate models of inclusive sub-regional growth and to examine how FE providers working in partnership with employers, local authorities and other social partners might support this aspiration.

\section{Building education-employer partnerships in London's NLSE context}

These dynamic contexts pose a distinct set of challenges for FE colleges and their relationship with local and regional social partners, including balancing the growth of specialist high level technical and vocational provision and showing a commitment to social 
inclusion; moving from a competitive provider logic to a more collaborative relationship with social partners to respond to strategic plans around regeneration and inclusive growth; increasing and deepening the level of employer partnership working; and acting as development hubs for SMEs.

Overarching these local collaborative efforts has been the ambivalence of national policy. While the Area-Based Reviews and devolution processes could be interpreted as a move towards a more planned and collaborative approach to post-16 education and training (see Hodgson and Spours, forthcoming), the Government has continued to incentivize the development of a marketised system through support for and promotion of a greater range of education providers competing for learners in the post-16 arena (Keep 2018).

Findings of the ELVET Programme - key lessons for partnership working

\section{Different sectors require different approaches}

In the majority of literature on employer engagement there is little, if any, discussion about the differences between sectors. Findings from earlier work on the Teach Too (UCL/AELP/ETF 2016), and Two-Way Street Leadership Exchange Programmes (Hodgson and Smith 2016), however, identified that building education-employer partnerships requires different approaches depending on the sector. The ELVET Programme was built on this premise and demonstrated very clearly that while there are common lessons for partnership working that can be applied to all sectors, the sectoral context is key. We therefore discuss briefly below the different issues and approaches in the three ELVET sectors. 


\section{Digital Tech}

According to the 2018 Tech Nation Report (2018) the total number of jobs in the UK digital tech economy was 2.1 million in 2017 and on the rise. There was a 32.2 percentage point increase between 2014 and 2017. Moreover, the proportion of jobs that now require digital expertise of some type is also increasing rapidly. The Government's UK Digital Strategy (DfDCM\&S 2017) predicts that by 2020, 90 per cent of all jobs will require some element of digital skills. However, the sector has a problem with diversity - only 19 per cent of the digital tech workforce is women and the percentage of those from black and ethnic minority groups is even lower at 15 per cent (Tech Nation 2018). London supports over 300,000 jobs in the digital tech sector and many of these are focused in East London around 'Silicon Roundabout', but there are considerable skills shortages in these areas with 58 per cent of start-ups in London claiming that that they lack highly-skilled workers (Tech Nation 2017).

The obvious areas for College A: Site 1 to work on in its ELVET innovation project were thus: skill building, increasing information about the opportunities in the sector, particularly for young women and black and ethnic minority groups, and ensuring that any partnership activity had mutual benefits for both parties.

What this college found when working with the digital tech sector was that many companies are SMEs, which, as we have seen earlier, brings particular challenges in terms of partnership working. One of the ways that it coped with this was by working with employer groups, such as the East London Business Alliance (ELBA), so that it could reach out more efficiently to a wider number of potential partners to discuss possibilities for work experience, apprenticeships and live projects. This was done through college staff attendance at ELBA meetings and events as well as through posts on ELBA's website and articles in its 
newsletter. It also ensured that staff and students were made aware of the various digital tech networks that exist in and around East London Tech City. These could be used for 'meet ups' where employers, tutors and students could talk to one another about new initiatives, possible employment opportunities and technological advances. In addition, College A: Site 1 had a considerable number of micro ed-tech businesses operating on its campus, which before the advent of the ELVET innovation project had not been fully exploited in terms of partnership activity, such as work placements for staff and students, technical expertise for digital tech courses, careers advice, apprenticeships, live projects (e.g. designing websites) and testing of ed tech products designed to appeal to young people. The benefits of this type of activity was obvious for the college, but it also met employers' needs for updating on the new apprenticeship standards and other government initiatives, upskilling the future workforce and providing access to a more diverse talent pool. For larger companies in the City of London, additional benefits included staff development for their early and middle career employees through offering technical and soft skills workshops for college students, as well as the more obvious brand recognition and corporate social responsibility benefits.

None of this was easy given that the digital tech sector primarily recruits graduates rather than Level 3 college students or apprentices, even though some of the jobs may well not require the higher level of skill. There is always a shortage of work experience placements and competition from other education providers in East London for access to these highly desirable employer partners. Moreover, at the time of the project, government policy meant that apprenticeships were being reformed, making it difficult to encourage employers to take on young people for an uncertain programme, and the college itself was being restructured as a result of the ABR process so not only had to cope with staff turnover but also found it difficult to project a clear mission and direction. Nevertheless, the beginnings of a new way 
of working with employers in the digital tech sector began to emerge as a result of the ELVET project and it was informing whole-college policy and practice in other sectors too.

\section{Creative Industries}

In many ways, the features of the Creative Industries sector have much in common with Digital Tech particularly in terms of large SME base and the project-based nature of employment. It is a highly important sector for both the UK and London and primarily recruits graduates from across the UK and internationally. The sector is particularly concentrated in East London (Regeneris 2018). In 2015 the gross value added of the creative industries in London was estimated at $£ 42$ billion and accounted for 12 per cent of the jobs in the capital, employing over 600,000 . One in four employees in this sector are self-employed. The proportion of women (36\%) and black and ethnic minorities (23\%) working in in the creative sector (Rocks 2017) is higher than in the Digital Tech sector, but still cause for concern. As with Digital Tech there are skills shortages in certain areas and a need for future skills development (Kumar 2017).

The innovation project in College A: Site 2 was designed to build partnerships with employers that would support young people from East London into employment and HE in the Creative Industries. Again, partnering with employer and sector training organisations, such as D\&AD and Creative Skillset, as well as highlighting the importance of networking for staff and students was crucial both in order to reach out and to develop the skills that are needed in this industry. Creating a trusted college 'brand' through constant contact between employers, college staff and students, being flexible, tailoring modules to local skills shortage areas, offering employers the opportunity to meet one another, to make connections with likeminded people and to use college facilities, as well as supporting students through 
showcasing their work in public creative spaces, proved particularly valuable. Discussions with employer partners in face-to-face meetings, workshops and through the formation of a college-employer forum which met on a termly basis, made college staff aware of the need for considerable updating of their own skills and the curriculum, current opportunities in the sector and the need for the development of student' soft skills. Employers were able to work with students on live projects, such as designing stage sets, to make sure they were taking on the most appropriate people for apprenticeships, for example, to influence curriculum development and to ensure a future talent pipeline. The issues College A: Site 2 faced in undertaking this project also very much mirrored those of their sister college noted above.

\section{Health and Social Care}

The position for College B working primarily with employers in adult social care was very different. While jobs in the Digital Tech and Creative Industries are often well paid and perceived as desirable, those in the social care sector are neither of these. Nevertheless, this sector employs around 1.45 million people in England and the number of jobs is growing as the population ages. It also has high levels of staff turnover - 28 per cent in 2016 and rising - and a nearly seven per cent $(90,000)$ vacancy rate (Skills for Care 2017), which was double in the local authority in which College B was situated. Unlike in the previous two sectors, the adult social care workforce is predominantly female (82\%) and low-skilled with an urgent need to upskill and retain staff.

Given this context, College B, unlike College A, found employers in this sector highly enthusiastic about engaging with it to support recruitment and retention and to upskill existing staff. The problem, however, was finding the time for discussion and training. Moreover, the original aim, which was to train staff in the use of assistive technologies, had 
to be delayed because staff in the sector had a greater need for more basic skills support in English, Mathematics and IT. College B, having initially discovered that employers were unable to attend events arranged specifically for them at the college, took a decision to go out to all the care homes in the locality to meet employers face-to-face and to undertake skills analyses. This strategy, though time-consuming, was ultimately much more successful, leading to individually tailored training and to the development of an e-learning module created in conjunction with Skills for Care, a national advocacy body for the sector. In return, the care homes were willing to support a number of different work experience opportunities for students on a range of courses, such as hospitality and catering, horticulture and painting and decorating, as well as health and social care. From a slow and laborious beginning, College B has now established a deep on-going partnership with both Skills for Care and local care homes in the local authority and beyond.

\section{Three generic lessons for partnership working}

Alongside these sector-specific lessons, the ELVET Programme, drawing particularly on the work of College $\mathrm{C}$, whose remit was to research models and strategies for forming educationemployer partnerships, identified three main generic findings which are discussed briefly below.

The importance of identifying benefits for employers - building sustainable educationemployer partnerships requires benefits for employers as well as education providers. Those identified during the ELVET Programme included - strategic long-term workforce development and succession planning to address skills gaps; co-designed and delivered programmes to meet employer needs; opportunities for staff development for both parties; 
joint project working whereby students and employers collaborate to create something new; and training needs analyses to support the development of bespoke employer-focused skills provision.

Communication strategies - evidence from the research undertaken by Colleges B and C, highlighted the importance of employers and providers creating the space to listen to one another, to try to understand each other's language and to conduct an honest and open dialogue about opportunities and constraints. The individual college Steering Groups of employers and college staff set up under ELVET provided one important mechanism for this kind of communication, but face-to-face contact, while highly valuable, is not always possible. Colleges having a website that speaks directly to employers as well as to students, with a clear point of contact, and using webinars and video-conferencing, all emerged as effective strategies. Employers fed back the need for both sides to be patient and to listen carefully to each partner's needs and constraints.

Network building - this activity constitutes a vital part of both communication strategies and making partnerships work. The ELVET innovation projects demonstrated the importance of working with a range of employer organisations, alliances, sectoral bodies and professional and trade associations, as well as brokerage organisations and community representatives, such as college governors. These networks provided cost- and time-effective ways of colleges gaining access to larger numbers of employers, gathering intelligence about future employment trends and new ways of working and finding advocates and ambassadors. From the employer perspective, particularly where SMEs are concerned, a network can support a menu of joint activities with a college or colleges that a single employer could not. The 
ELVET innovation projects also found that networking was a skill that both college staff and students needed to practice for their own career development and employment prospects.

\section{Building the conditions for partnership and skills co-production}

The ELVET Programme showed not only what could work in current conditions, but what also needed to happen in order to build and sustain partnership working and skills coproduction in the context of the NLSE.

\section{Changes to college structures and partnership working}

Partnership building requires a balance between (a) a dedicated generic central service within a college that provides expertise on partnership working and has a single portal to provide easy access for employers and (b) the development of smaller-scale, sector-specific relationships between curriculum area specialists and employers that support more detailed dialogue and action to cater for the differences between the sectors, highlighted in the ELVET Programme. Given the size and dispersed nature of the new multi-site colleges resulting from the $\mathrm{ABR}$ process, attention also needs to be given to how these larger units will work to serve the needs of specific sectors and also different local areas. No one successful model emerged from the ELVET Programme.

\section{Towards 'High Progression and Skills Networks' - necessities and limitations}

In the context of the NLSE and the way it manifests itself in London's East, a major lesson from the ELVET Programme was the need not only to move from employer engagement to two-way partnerships, but also to involve a wider range of local and regional social partners, supported by national government. However, such a move will be a challenging long-term 
project insofar as it will require the establishment of new types of collaboration and changes to institutional mindsets.

Developing effective and up-to-date vocational education and training hubs that open up opportunities for local communities to access employment and to contribute to local and subregional economic development, means that education-employer partnerships need to expand their reach to work with a wide range of external partners (e.g. local authorities, Local Enterprise Partnerships, community groups, other education and training providers, HE institutions). Because of their historic and deep-rooted connection with their communities, colleges are ideally placed to act as connectors between these wider partners and to offer a leadership role in relation to technical and vocational education that provides progression routes into and within employment.

This form of sustained partnership working, however, requires a new level of collaboration on local and sub-regional terrains. Coinciding with the ELVET Programme was the development of Sub-Regional Skills and Employment Boards, following London's ABR process. The ELVET Programme suggested that these could be conceptualized as potential 'High Progression and Skills Networks' (HPSNs) in which FE providers, along with other social partners, such as employers, local HE institutions and local government, collaborate to identify the 'key problem terrains' - the main challenges they face together in building innovative enterprises to transform the local economy and improve the lives of local citizens.

Figure 1 about here 
Within these HPSNs different local social partners could bring their distinctive but complementary contributions to the problem. Working through new forms of partnership, this 'synergy of difference' provides the possibility for innovative collaborative solutions to emerge. More specifically, the collaborative building of an HPSN would include: coconstructing an understanding of future work opportunities at the whole range of skill levels and across all sectors with their different configurations within a locality/sub-region; codesigning programmes to secure employment and effective progression routes into and within work for local people; and working in partnership to exchange services for skill development.

At the same time, the research pointed up the power of national policy, the ingrained habits of institutional competition and the influence of a largely unregulated labour market that slow the progress of new patterns of partnership working. Keep (2016) reminds us that the powers devolved to local government are at best partial and that historical centralizing powers remain strong. Constructive building from below is clearly required in the current era. At the same time, however, it would be unwise to over-estimate the powers of 'horizontal' networking and governance at the local and regional levels in the absence of helpful 'vertical frameworks' coming from national government and national agencies. If new patterns of partnership working are to become a permanent and dominant feature of the education and skills landscape, national government is going to have to play its part in facilitating the conditions for them to thrive. 


\section{References}

Bach, S. 2016. Deprivileging the public sector workforce: Austerity, fragmentation and service withdrawal in Britain The Economics and Labour Review 27 (1) https://doi.org/10.1177/1035304615627950

Berry, C., Maddern, N., Casey, L. and A. Corley, 2014. London FE Colleges’ Employer Engagement. Available at:

https://lep.london/sites/default/files/documents/publication/FE\%20Colleges\%20Employer\%2 0Engagement.pdf, accessed 22 June 2017

Bridgwood, A. 1987. Technical and vocational education: a comparison between initiatives in Britain and abroad. Education Research, 29 (3) 163-172.

Clarke, L and, C. Winch (eds). 2007. Vocational education, international approaches, development and systems. London: Routledge.

Commission on Adult Vocational Teaching and Learning (CAVTL) 2013. It's about work... https://www.excellencegateway.org.uk/content/eg5937, accessed 17 October 2018.

Department for Business Innovation and Skills/Department for Education (DBIS/DfE) 2016. Post-16 Skills Plan. Available at: https://assets.publishing.service.gov.uk/government/uploads/system/uploads/attachment __data/file/536043/Post-16_Skills_Plan.pdf, accessed 14 August 2018.

Department for Digital Culture Media and Sport (DfDCM\&S) 2017. Digital skills and inclusion: giving everyone access to the digital skills they need. Available at: https://www.gov.uk/government/publications/uk-digital-strategy/2-digital-skills-andinclusion-giving-everyone-access-to-the-digital-skills-they-need, accessed 17 September 2018.

Department for Education and Employment (DfEE) 1998. The Learning Age: a renaissance for a New Britain. London: DfEE 
DfES (Department of Education and Skills) 2006. Further education: raising skills, improving life chances. London: DfES.

Dhillon, B., Edmonds, T., A. Felce, 2011. Making employer and university partnereships work: accredited employer-led training. Farringdon: Libn.

Dolphin, T. and T. Lanning, 2011. Rethinking apprenticeships. https://www.aoc.co.uk/sites/default/files/IPPR_Rethinking_Apprenticeships_Nov_2011 .pdf, Accessed 17 October 2018.

Education and Employers Taskforce 2009. Defining effective employer engagement.

Available at: https://www.educationandemployers.org/wp-

content/uploads/2014/06/eet01-defining-effective-employer-engagement-2009.pdf

Accessed 27 February 2018

European Commission 2010. Education \& Training: Modernising Education and Training: A Vital Contribution to Prosperity and Social Cohesion in Europe. Available at: https://eur-lex.europa.eu/legalcontent/EN/TXT/HTML/?uri=CELEX:52005SC1415\&from=EN, accessed 10 September 2018.

EY Foundation 2016. The employment landscape for young people in the UK: challenges and opportunities.

https://www.ey.com/Publication/vwLUAssets/Employment_landscape_for_young_peo ple_in_the_UK/\$FILE/Employment\%20landscape\%20for\%20young\%20people\%20in \%20the\%20UK\%20-\%20final\%20report.pdf, Accessed 16 October 2018.

Finegold, D. and D. Soskice, 1988. The failure of training in Britain: analysis and prescription. Oxford Review of Economic Policy, 4 (3) 21-53.

Flynn, M., Pillay, H. and J. Watters, 2016. Industry-school partnerships: boundary crossing to enable school to work transitions. Journal of Education and Work, 29 (3) 309-33. 
Foster, A. 2005. Realising the potential: a review of the future role of further education colleges. London: DfES.

Fuller, A. and L. Unwin, 2003).Learning as apprentices in the contemporary UK workplace: creating and managing expansive and restrictive participation. Journal of Education and Work, 16 (4) 407-426.

Fuller, A. and L. Unwin, 2010. Knowledge workers as the new apprentices: the influence of organisational autonomy, goals and values on the nurturing of expertise. Vocations and Learning, 3 (3) 201-222.

Greater London Authority (GLA) 2018. Skills for Londoners: a skills and adult education strategy for London. Available at: https://www.london.gov.uk/sites/default/files/sfl_strategy_final_june_20186.pdf

Green, F. and G. Henseke, G. 2016 The changing graduate labour market: analysis using a new indicator of graduate jobs Journal of Labor Policy, 5 (14) doi: 10.1186/s40173$\underline{016-0070-0}$

Her Majesty's Government (HMG) 2013. The future of apprenticeships in England: implementation plan. Available at: https://assets.publishing.service.gov.uk/government/uploads/system/uploads/attachment _data/file/253073/bis-13-1175-future-of-apprenticeships-in-england-implementationplan.pdf, accessed 3 September 2018.

HMG 2015a. English apprenticeships: our 2020 vision. Available at: https://www.gov.uk/government/uploads/system/uploads/attachment_data/file/482754/ BIS-15-604-english-apprenticeships-our-2020-vision.pdf

HMG 2015b. Reviewing post-16 education and training institutions. Available at: https://www.gov.uk/government/uploads/system/uploads/attachment_data/file/446516/ BIS-15-433-reviewing-post-16-education-policy.pdf 
HMG 2016. The Cities and Local Government Devolution Act. Available at:

http://www.legislation.gov.uk/ukpga/2016/1/contents/enacted

HMG 2017. Industrial Strategy: building a Britain fit for the future. Available at:

https://assets.publishing.service.gov.uk/government/uploads/system/uploads/attachment _data/file/664563/industrial-strategy-white-paper-web-ready-version.pdf, accessed 14

August 2018.

Hernandez-Gantes, V., Keighobadi, S. and E. Fletcher, 2018. Building community bonds, bridges and linkages to promote the career readiness of high school students in the United States. Journal of Education and Work 31 (2) 190-203.

Hodgson, A. and D. Smith, 2016. Two-Way Street Leadership Exchange Projects: Final National Report. Available at: http://www.ucl.ac.uk/ioe/clients-partners/consultancyservices/pdf/two-way-street-final-national-report-feb-2016.pdf, accessed 17 September 2018.

Hodgson, A., and K. Spours, 2014. "Heavy fog in the Channel: Continent cut off': The reform of upper secondary education from the perspective of English exceptionalism." European Educational Research Journal 13 (6): 683-698.

Hodgson, A. and Spours, K. (2015) 'The future for FE colleges in England: the case for a new Post-Incorporation model' in The Coming of Age of FE? Edited by A. Hodgson. London: IOE Press.

Hodgson, A. and K. Spours, 2018. A social ecosystem model: conceptualizing and connecting working, living and learning in London's New East. Available at: https://elvetlondon.co.uk/protected/resources.php, accessed 18 September 2018. 
Hodgson, A. and K. Spours, forthcoming. Further education in England: at the crossroads between a national competitive sector and a locally collaborative system? Journal of Education and Work.

Holmes, C. and K. Mayhew, 2012. The Changing Shape of the UK Job Market and its Implications for the Bottom Half of Earners London: Resolution Foundation

House of Commons 2011. Localism Act. Available at: https://services.parliament.uk/bills/2010-12/localism.html, accessed 13 September 2018/

Huddleston, P., Mann, A. and J. Dawkins, 2014. 'That aroma of where they are likely to go: employer engagement in high performing English independent schools', in A. Mann, J. Stanley, J. and L. Archer (eds), Understanding employer engagement in education: theories and research, London: Routledge.

Keep, E. (2012) Education and industry: taking two steps back and reflecting. Journal of Education and Work, 25 (4): 357-379.

Keep, E. 2015. Governance in English VET: On the functioning of a fractured 'system' Research in Comparative and International Education 10 (4) https://doi.org/10.1177/1745499915612185

Keep, E. 2016. The long-term implications of devolution and localism for FE in England London: AoC.

Keep, E. 2018. Scripting the future-exploring potential strategic leadership responses to the marketization of English FE and vocational provision. Available at: http://fetl.org.uk/wp-content/uploads/2018/07/FETL_scriptingthefuture-web.pdf, accessed 13 September 2018.

Kumar. S. 2017. Upskilling the UK's creative industries, New Statesman, July. p. 20-21. 
London Councils/London Enterprise Panel/Mayor of London (2015) Skills devolution for London: a proposal to government. Available at: https://lep.london/sites/default/files/Skills\%20Devo.pdf

London First 2018. An Employment and Skills Action Plan for London. Available at: https://www.londonfirst.co.uk/sites/default/files/documents/201806/SkillsandEmploymentActionPlan_0.pdf, accessed 13 September 2018.

Local Government Group (LGG)/British Chambers of Commerce (BCC) and 157 Group 2011. The role of local enterprise partnerships in tackling skills needs. Available at: https://www.excellencegateway.org.uk/content/import-pdf17096, accessed 13 September 2018.

London Growth Boroughs 2016. London's Growth Boroughs http://www.growthboroughs.com Accessed 4 January 2016

Macleod, D. and M. Hughes, 2005. What we know about working with employers: a synthesis of LSDA work on employer engagement. London: LSDA.

Mann, A. and C. Percy, 2013 Employer engagement in British secondary education: wage earning outcomes experienced by young adults. Journal of Education and Work, 27 (5), 496-495.

Mann, A., Rehill, J. and E. Kashefpakdel, 2018. Employer engagement in education:insights from international evidence for effective practice and future research. https://educationendowmentfoundation.org.uk/public/files/Employer_Engagement_in_ Education.pdf, accessed 17 October 2018.

Mayor of London 2016. A City for All Londoners London: Gov UK.

Melhuish, L. 2017. Dangerous liaisons: exploring employer engagement relationships in a vocational undergraduate adventure and outdoor management degree. Industry and Higher Education, 31 (1) pp. 3-10. 
Moon, J. and J.J. Richardson, 1984. Policy-making with a difference? The Technical and Vocational Education Initiative. Public Administration, 62 (1) 23-33.

Muntaner, C. 2018. Digital Platforms, Gig Economy, Precarious Employment, and the Invisible Hand of Social Class International Journal of Health Services, 48 (2) https://doi.org/10.1177/0020731418801413

New Policy Institute (NPI) 2017. London's poverty profile 2017 http://www.npi.org.uk/publications/income-and-poverty/londons-poverty-profile-2017/ (accessed 21 January 2018).

Office for Standards in Education, Children's Services and Skills (Ofsted) 2015. Engaging small and medium enterprises in work experience and apprenticeship in London, Available at: https://www.gov.uk/government/uploads/system/uploads/attachment_data/file/395355/ Engaging_small_and_medium$\underline{\text { sized_enterprises_in_work_experience_and_apprenticeships_in_London.pdf }}$, accessed 22 June 2017.

Organisation for Economic Co-operation and Development (OECD) 2014. Skills beyond school: synthesis report. Paris: OECD Publishing.

Polesel, J., Klatt, M., Blake, D. and K. Starr, 2017. Understanding the nature of school partnerships with business in delivery of vocational programmes in schools in Australia. Journal of Education and Work 30 (3) 283-298

Regeneris 2018. LLDC Combined Economy Study. Part B: Creative and Cultural Opportunities Assessment. Available at: http://www.queenelizabetholympicpark.co.uk//media/lldc/local-plan/local-plan-review-2017/evidence-reports-april-2018/part-b--

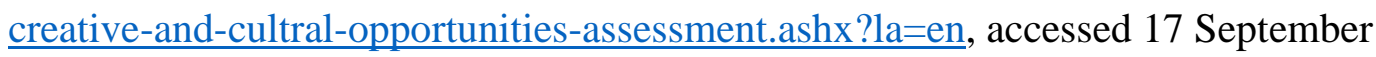
2018. 
Rocks, C. 2017. London's Creative Industries - 2017 update. Available at:

https://www.london.gov.uk/sites/default/files/working_paper_89-creative-industries2017.pdf, accessed 17 September 2018.

Rustien, G. and B. Hermelen, 2017. Cross-sector collaboration in upper secondary school vocational education experiences from two industrial towns in Sweden and Norway. Journal of Education and Work 30 (8) 813-826.

Sharp, M. 2011. A dynamic nucleus: colleges at the heart of local communities. Available at: https://www.aoc.co.uk/files/dynamic-nucleus-colleges-the-heart-local-communitiespdf$\underline{0}$, accessed 13 September 2018.

Skills for Care 2017. The state of the adult social care sector and workforce in England. Available at: https://www.skillsforcare.org.uk/Documents/NMDS-SC-andintelligence/NMDS-SC/Analysis-pages/State-of-17/State-of-the-adult-social-caresector-and-workforce-2017.pdf, accessed 18 September 2018.

Tech Nation 2017. London. Available at: https://technation.techcityuk.com/cluster/london/, accessed 17 September 2018.

Tech Nation 2018. 2018 Tech Nation Report. Available at: https://technation.io/insights/report-2018/jobs-and-skills/, accessed 17 September 2018. Tenreyo, S. 2018. The fall in productivity growth: causes and implications. Lecture at Queen Mary College, London, 15 January. https://www.bankofengland.co.uk//media/boe/files/speech/2018/the-fall-in-productivity-growth-causes-and-implications. Accessed 16 October 2018

Thompson, S., Colebrook, C and I. Hatfield, 2016. Jobs and skills in London: building a more responsive system in the Capital. London: IPPR. 
Todoli-Signes, A. 2017. The 'gig economy': employee, self-employed or the need for a special employment regulation? European Review of Labour and Research 23 (2) ttps://doi.org/10.1177/1024258917701381

UCL IOE/AELP/ETF2016. Teach Too: findings from the development programme Phase 1. Available at: https://technation.io/insights/report-2018/jobs-and-skills/, accessed 17 September 2018.

UK Commission for Employment and Skills UKCES. (2014) Climbing the ladder: skills for sustainable recovery. https://assets.publishing.service.gov.uk/government/uploads/system/uploads/attachment _data/file/378968/Summer_What_0v41.pdf, accessed 16 October 2018.

UKCES/157 Group/Gazelle Colleges 2014. A New Conversation: Employer and College Engagement. https://assets.publishing.service.gov.uk/government/uploads/system/uploads/attachment _data/file/306968/A_New_Conversation.pdf, accessed 17 October 2018.

Universities UK 2015. Patterns and Trends in UK Higher Education 2015 London: Universities UK.

Wadsworth, J. 2015. Immigration and the UK Labour Market LSE Centre for Economic Performance http://cep.lse.ac.uk/pubs/download/EA019.pdf (Accessed 12 February 2019)

Wettenhall, R. 2001. Public or Private? Public Corporations, Companies and the Decline of the Middle Ground Public Organisation Review, 1 (1) 17-40.

Wolf, A. 2011. Review of Vocational Education: the Wolf Report. London: DfE. 
Figure 1. High Progression and Skills Networks

Mediation of relations from above - the State

Mediation of relations from below - the Community

Local government economic regeneration and service provision
Industrial \& business clusters involving a range of different types of enterprises

Evolution over time

\section{Shared mission of} inclusiveand sustainable economic and social education colleges as VET and progression hubs 